


\section{Online folyóirat}

Szerkesztette: VÁGÁNY Judit Bernadett, PhD - FENYVESI Éva, PhD

Borító: FLOW PR

Kiadja: Budapesti Gazdasági Egyetem, Kereskedelmi, Vendéglátóipari és Idegenforgalmi Kar, Közgazdasági és Üzleti Tudományok Tanszék

Felelős kiadó: FENYVESI Éva, PhD

a Közgazdasági és Üzleti Tudományok Tanszék vezetője

ISSN 2630-886X

2020. 


\title{
BIZTOSÍTÓK TÁRSADALMI FELELŐSSÉGVÁLLALÁSA
}

\section{SOCIAL RESPONSIBILITY OF INSURANCE COMPANIES}

\author{
KONTÓ Gizella - BAJZA István
}

Kulcsszavak: társadalmi felelösségvállalás, CSR, környezettudatosság, bižtositó társaságok Keywords: CSR, enviromental sustainability, insurance companies

JEL kód: G22, G32, L29, M31, Q59 


\section{ÖSSZEFOGLALÓ}

Változó, globalizálódó világunkban egyre erösödik a lokális cselekvés a gazdaság szereplöinek azon felismerése, hogy felelösséget hordoznak környezetük és a társadalom iránt. Egyre fontosabbá válik az. is, hogy hogyan vélekednek az egyének a vállalatról, annak értékfolyamatban betöltött szerepéröl. Kutatásunk a CSR elterjedtségét vizsgálta a piaci szereplök egy szegmensében, a biztositó társaságoknál. Hipotézisek: H1: Csak a nagyobb biztositók végeznek CSR tevékenységet. H2: A CSR tevékenység formája nem tér el lényegesen a nagy biztositók közö̈t. H3: A CSR programok közöott legnagyobb ráforditást a támogatás képvisel. H4: A CSR tevékenységre az éves müködési eredmények kevesebb, mint 5\%-át költike a biztositók

Módszertan: Szekunder kutatás a biztositók weboldalán található CSR jelentésekböl. Kiemeleten kezeljük az, 5 legnagyobb vagyonú biztositó CSR szerepvállalását. Primer kvantitatív kutatás önkitöltös elektronikus kérdöiv formájában, melyet 13 olyan biztositóboz juttattunk el, akik a bonlapjuk szerint folytatnak CSR tevékenységet.

Eredmények: Örömteli, hogy a gazdálkodó cégek és a banki saféra nyomdokain haladva a biztositási piacon is egyre nagyobb teret hódit a CSR. A kisebb biztositók fóként támogatások, adományok formájában, míg a nagyok szélesebb körü akciókkeal valósitják meg a CSR teendöket. A nagy biztositó társaságok CSR tevékenysége nem tér el lényegesen egymástól: támogatásokra, az alkalmazottak önkéntességére és a környezet kimélésére épitenek. Fontos kihangsúlyozni, hogy az oktatás terén igyekeznek a lakosságot és föleg a fiatalokat érzékenyiteni az egészségmegörzés, a baleset-és kármegelözés, továbbá a biztonság és a biztositások, mint pénqügyi szolgáltatások terén. Közös sajátosság a sport, egészség kiemelt megjelenése a támogatásokban, ám több biztositó is országos hirú sportklubokat vagy magyar válogatottat saponzorál, ami nem feltétlenül jelent valódi társadalmi felelösségvállalást, sokekal inkább reklámfelületet a biztositó intéz̨et számára. A kérdôives mérés szerint a CSR tevékenységre az éves eredménynek csupán kevesebb, mint 5\%-át költik a biztositó társaságok.

\section{SUMMARY}

In our changing, globalizing world, local action is increasingly becoming a reality for economic actors to take responsibility for their environment and society. It is becoming increasingly important how individuals perceive the role of the company in its value process. Our research investigated how widespread the CSR in a segment of market participants, insurance companies.

Hypotheses: H1: Only major insurance companies perform CSR activities. H2: The form of CSR activity does not differ significantly between them. H3: Support is the biggest investment between CSR programs. H4: They spend less than 5\% of annual operating results on CSR activities

Methodology: Secondary research from CSR reports on insurance companies' websites. We are focusing on the role of the 5 largest among them. Primary quantitative research in a survey of a self-contained electronic questionnaire sent to 13 insurers who perform CSR activities according to their website.

Results: We are pleased to see that CSR is gaining ground in the insurance market as a result of companies and the banking sector. Smaller insurance companies mainly use grants and donations, while the larger ones carry out CSR actions with a wider range of actions. CSR activities of large insurance companies do not differ significantly: they are built on support, volunteering for employees and the environment. It is important to emphasize that in the field of education, people are trying to sensitize the 
population and especially young people in terms of health care, accident and injury prevention, as well as security and insurance as financial services. A common feature of sport is the prominent appearance of sports, but many insurance companies sponsor nationally-recognized sports clubs or Hungarian national teams, which does not necessarily imply real social responsibility, but rather an advertising space for the insurance institution. According to the questionnaire survey, insurance companies spend less than 5\% of the annual profit on CSR activity.

\section{BEVEZETÉS}

Változó, globalizálódó világunkban egyre erősödik a lokális cselekvés, a közvetlen közösségi kapcsolatok iránti igény. Ennek egy újszerű eleme a gazdaság szereplőinek azon felismerése, hogy felelősséget hordoznak környezetük és a társadalom iránt. Egyre fontosabbá válik az is, hogy hogyan vélekednek az egyének a vállalatról, annak értékfolyamatban betöltött szerepéről.

A világháló hatalmas lehetőségeket, de ugyanilyen mértékű kockázatokat is hordoz egy cég megítélésével kapcsolatban. Vigyázni kell a jó hírnévre, fokozatosan felépítve a pozitív kötődés lehetőségét is. Erre kiváló keret a CSR, ami segít tudatosan formálni a kívánatos önképet, összekapcsolva a fontosnak tartott ügyeket a gazdaság adott szereplőivel. Izgalmas kérdéssé vált a Társadalmi Felelősségvállalás ügye.

Tanulmányunk vizsgálja e fontos tevékenységet, külön szegmensként vizsgáljuk a pénzügyi piacon belül a biztosítási szektort.

\section{Hipotézisek:}

H1: Csak a nagyobb biztosítók végeznek CSR / társadalmi felelősségvállalási / fenntartható fejlődési tevékenységet.

H2: A CSR tevékenység formája nem tér el lényegesen a nagy biztosítók között.

H3: A CSR programok között legnagyobb ráfordítást a támogatás képvisel.

H4: A CSR tevékenységre az éves működési eredmények kevesebb, mint 5\%-át költik a biztosítók.

\section{MÓDSZERTAN}

Szekunder kutatás a biztosítók weboldalán található CSR / társadalmi felelősségvállalási / fenntartható fejlődési jelentésekből. Kiemeleten kezeljük az 5 legnagyobb vagyonú biztosító CSR szerepvállalását.

Primer kvantitatív kutatás önkitöltős elektronikus kérdőív formájában, melyet 13 olyan biztosítóhoz juttattunk el, akik a honlapjuk szerint folytatnak CSR / társadalmi felelősségvállalási / fenntartható fejlődési tevékenységet.

Rövidítések: CSR - Corporate Social Responsibility, TF - Társadalmi Felelősségvállalás, FF - Fenntartható Fejlődés 


\section{SZAKIRODALOM FELDOLGOZÁS}

\section{A vállalati társadalmi felelősség (CSR)}

A vállalati társadalmi felelősség (Corporate Social Responsibility) jelentős térnyerése figyelhető meg az elmúlt évtizedekben. A CSR jelenlegi megközelítései messze túlmutatnak a fogalom korai értelmezésén, amikor a menedzserek kapcsán vetődött fel az, hogy nemcsak gazdasági felelősségük van a tulajdonosok felé, hanem társadalmi felelősségük is a társadalom felé.

A CSR-piramis (1. ábra) szemlélteti a felelősség különböző rétegeit. Az alapot a gazdasági felelősség jelenti. Ezzel egy időben a vállalatoknak meg kell felelniük a jogi normáknak. Az etikai felelősség alapvető szintje a helyes, igazságos, tisztességes viselkedés kötelezettsége, és túlmutat a jogszabályoknak való megfelelésen. Ezeken felül jelenhet meg a diszkrecionális vagy jótékonysági felelősség (Carroll, 1991).

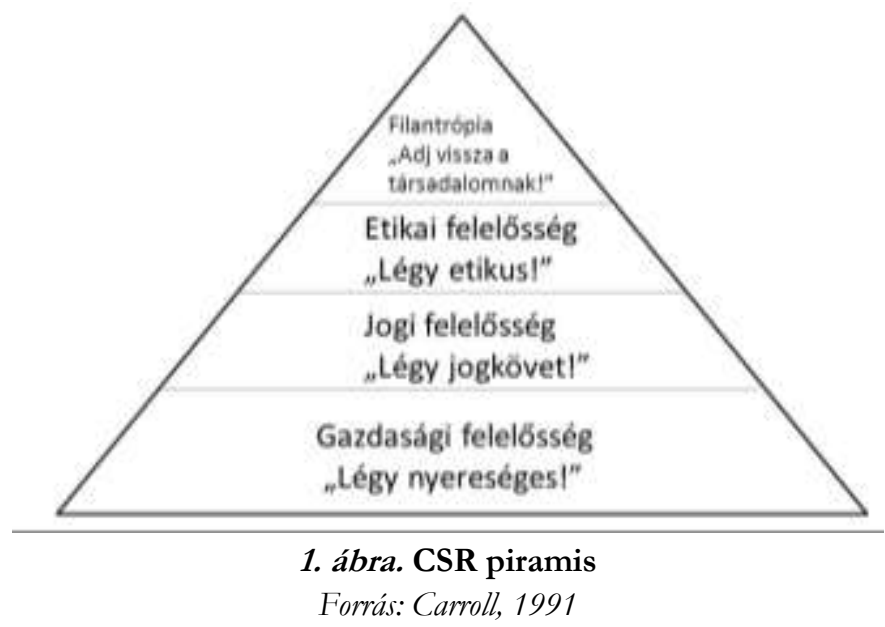

A CSR-definíciók különböző változatai a felelősségvállalás öt fő dimenzióját különböztetik meg (Braun, 2007):

1. Környezeti (tisztább környezet, környezetgazdálkodás, az üzleti tevékenység környezeti szempontjai).

2. Társadalmi (a társadalom jobbá tétele, a társadalmi szempontok integrálása az üzleti tevékenységbe, a vállalat társadalomra és közösségre gyakorolt pozitív és negatív hatása).

3. Gazdasági (a gazdasági fejlődéshez való hozzájárulás, hosszú távú nyereségesség).

4. Stakeholder (érintettek kezelése, párbeszéd az érintettekkel, érintettek bevonása)

5. Önkéntességi (a kötelező jogszabályokon túlmutató, önkéntes tevékenység)

Tehát a CSR-ben megjelennek a fenntartható fejlődés gazdasági, társadalmi, környezeti pillérei, kiegészítve a stakeholder-megközelítéssel és az önkéntességi dimenzióval. A 
stakeholder-megközelítés tipikusan a vállalati szféra kapcsán jelent meg, mint etikai kötelesség.

A gyakorlatban azonban a vállalatok többségénél a CSR kapcsán még mindig jótékonysági programokkal találkozunk, jelentôs részüknél célként jelenik meg a müködési hatékonyság növelése, azonban a vállalatok csak kis részénél érzékelhető az üzleti modell valódi átalakításának igénye (Rangan, 2015). A fenntartható fejlődés koncepciója felveti azt, hogy minden vállalkozásnak egyben társadalmi vállalkozásnak is kellene lennie, harmóniát teremtve a gazdasági, környezeti és társadalmi célok között, hozzájárulva ezzel a fenntartható fejlődéshez.

\section{Pénzintézetek társadalmi felelőssége}

A CSR kihívásaira a bankszektor viszonylag későn reagált. Előbb környezeti kérdésekkel foglalkoztak, majd ezt követték a társadalmi kérdések (Vigano, 2009). A CSR szerepe a pénzügyi szférában megjelenő eszközként arra szolgál, hogy növelje és legitimálja annak gazdasági teljesítményét, másrészt megjelenik az üzleti etikai alapelvek megtestesítőjeként is.

A 2008-as pénzügyi válság ráirányította a figyelmet a CSR szükségességére ebben a szférában is, felerősítve a bizalom és az ezt elősegítő elszámoltathatóság és transzparencia iránti igényt. A pénzügyi intézmények hagyományosan fő társadalmi funkciójának a közvetítő szerepet tekintik, amely a megtakarításokat közvetíti a befektetések felé, a hatékony allokáció és kockázatmenedzsment figyelembevételével. Ugyanakkor emellett az etikus és felelős viselkedés iránti igény hatására a pénzügyi és befektetési folyamat az elmúlt években túlmutat a betétesek és tulajdonosok legitim érdekeinek védelmén (TzuKuan Chiu, 2014).

A 2. ábra a banki aktivitás (mérlegfőösszeg és a fiókok számának függvénye) és a CSR aktivitás függvényében mutatja a jellemző banki CSR-területeket. A CSR-aktivitás azt mutatja, hogy annál inkább beintegrálja a bank üzleti tevékenységébe a CSRkezdeményezéseket, minél nagyobb a gazdasági potenciálja. Ugyanakkor kisebb mérlegfőösszegű bankok esetében csupán a jótékonysági szempont jelenik meg. 


\begin{tabular}{|c|c|c|c|}
\hline \multicolumn{4}{|c|}{ BANKI CSR-TÉRKÉP } \\
\hline \multirow{4}{*}{ 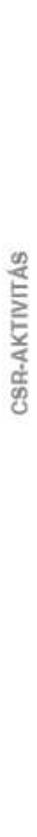 } & 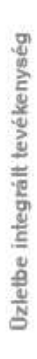 & 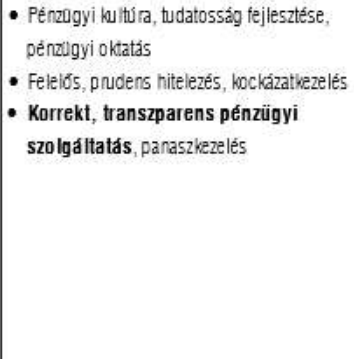 & 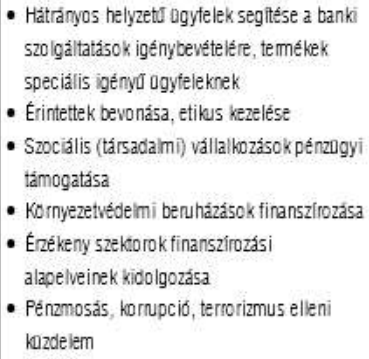 \\
\hline & 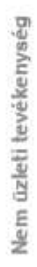 & $\begin{array}{l}\text { - Onkéntes akciók a helyi lakókornyezet } \\
\text { javitására } \\
\text { - Hátrányos helyzetí társadalmi csoportok } \\
\text { támogatása } \\
\text { - Helyi kozosség támogatása } \\
\text { - Sport támogatása } \\
\text { - Civil szervezzetek támogatása } \\
\text { - Kultúra és mavészet támogatása }\end{array}$ & 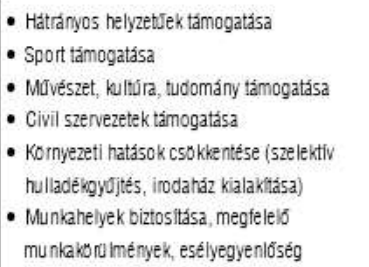 \\
\hline & \multicolumn{3}{|c|}{ BANKI AKTIVITÁS } \\
\hline & \multicolumn{3}{|c|}{ 2. ábra. Banki CSR-térkép } \\
\hline
\end{tabular}

Egyre többen vannak azon a véleményen, hogy az üzleti döntéshozatalnál nemcsak a profitmaximalizálást kell szem előtt tartani, hanem azt is, hogy az üzleti szervezetek önkéntes alapon járuljanak hozzá a társadalmi problémák megoldásához, ami nem gazdasági érdekük, hanem morális kötelességük (Barclift, 2012).

A 2006-os CSR kutatás a hazai pénzügyi szektorban (GfK - Braun \& Partners) a következő kritikai megállapításokkal élt (Braun, 2007):

1. Az 5 legnagyobb mérlegfőösszegű bank CSR-tevékenysége minimális. Főként HR (képzés, fejlesztés, juttatások) és környezetvédelem területen tevékenyek.

2. A pénzügyi tudatosság növelése/transzparencia nem kiemelt téma (leginkább szponzoráció).

3. A vállalati programok a vezetők személyes elkötelezettségét és/vagy a külföldi tulajdonos elvárásait tükrözik.

4. Kevesen kezelik a társadalmi felelősséget a tudatos stratégia részeként.

5. Erős a félelem a társadalmi felelősségvállalás kommunikációjával kapcsolatban („Hogyan fogadnák az érintettek a vállalat CSR-tevékenységét?”).

6. Bár a legtöbben az ügyfeleket emelték ki, mint legfontosabb érintetteket, csupán egy vállalat kérte ki ügyfelei véleményét a társadalmi felelősségvállalásról. 
És két pozitív, előre vivő következtetés is megfogalmazódott a kutatás kapcsán:

1. A várakozások szerint a CSR néhány éven belül megkülönböztető, versenyelőnyt biztosító tényezôvé válhat.

2. A társadalmi felelősségvállalási tevékenységek várhatóan sokszínűbbé, egyedibbé és strukturáltabbá válnak.

\section{EREDMÉNYEK}

\section{Biztosítók gazdasági teljesítménye}

A pénzintézetek speciális ágazata a biztosítási piac. Tevékenységük kiterjed az élet-, nyugdíj-, egészség-, gépjármű-, lakás-, egyéb lakossági, illetve a vállalkozói biztosításokra, valamint a kármegelőzésre.

A Magyar biztosítók évkönyve adatai szerint 2015 és 2017 között a dijbevétel squerinti rangsor elején az 5 biztosító a következő (csökkenő sorrendben): 1. Allianz, 2. Generali, 3. Aegon, 4. Groupama, 5. NN (a díjbevételek 100.000-150.000 M Ft között szóródnak, 3. ábra) Ugyanezen forrás adatai szerint 2015 és 2017 között a piaci részesedés szerinti rangsor elején az 5 biztosító a következő (csökkenő sorrendben): 1. Allianz, 2. Generali, 3. Groupama, 4. Aegon, 5. NN (a részesedések 9-15\% között szóródnak, 3. ábra).

Az 5 legnagyobb biztosító adja a díjbevételek, és a piaci részesedés csaknem 60\%-át. Ezért a CSR tevékenység vizsgálatánál őket fogjuk kiemelten elemezni.

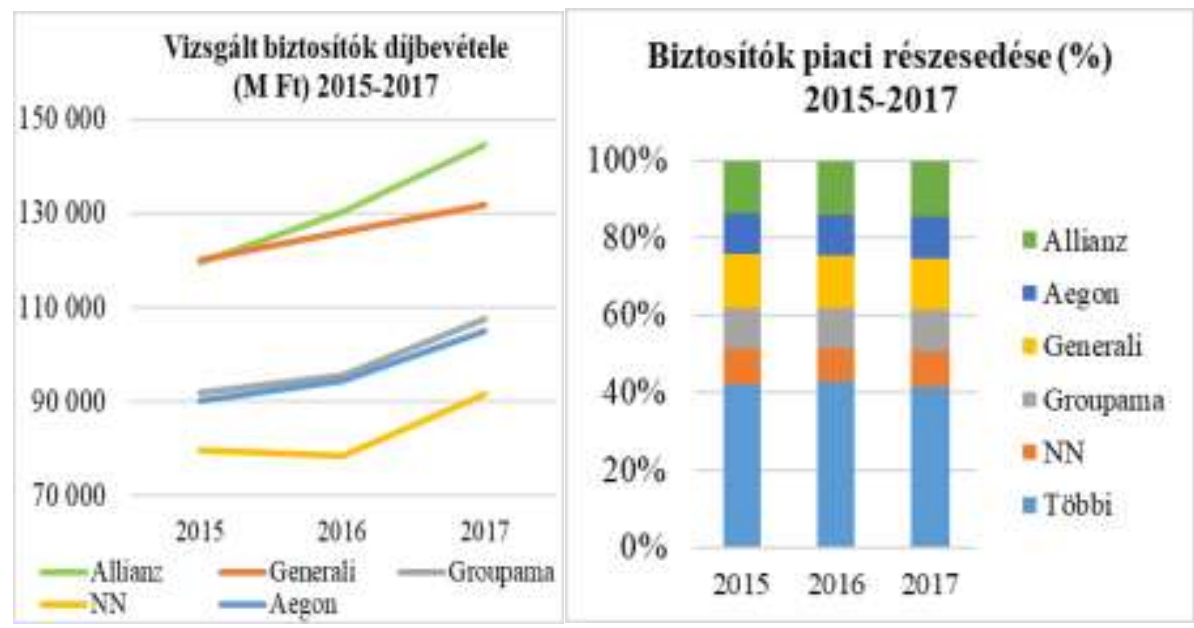

3. ábra. A vizsgált 5 nagy biztosító bruttó díjbevétele és piaci részesedése

Forrás: Magyar biz̨ositók évkönyve, 2018 - saját szerkesztés

Ahogy a 4. ábra mutatja - 2017. év végi adatok -, a biztosítók vagyona alapján első helyen áll az NN (kb. 400.000 M Ft), nagyjából 25\%-kal megelőzve a közvetlenül mögötte állókat - Allianz-t, Groupama-t és a Generalit -, akik hozzávetőleg azonos vagyonnal rendelkeznek (kb. 300.000 M Ft). Kissé leszakad tőlük a vagyon terén az Aegon, kb. 
feleakkora összeggel (kb. 200.000 M Ft), mint az NN, illetve kb. kétharmad akkorával, mint az Allianz, Groupama és a Generali.

Egyedül az Allianz tartja az 1.-2. helyezést mindhárom vizsgált eredményességi mutatóban (pozitív korreláció).

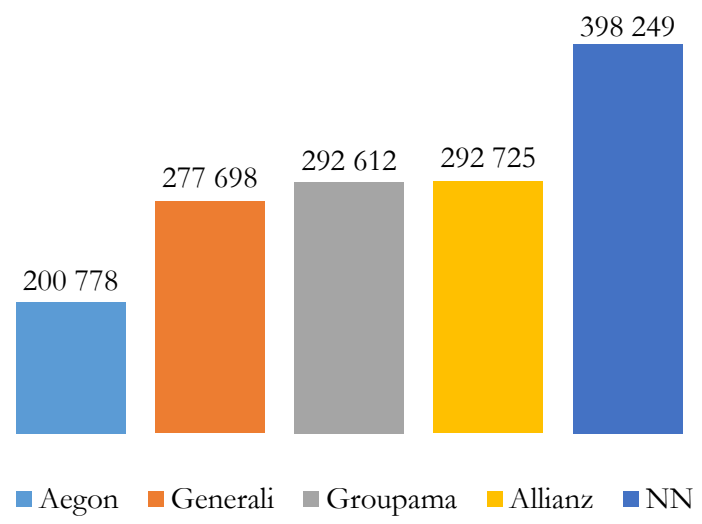

4. ábra. A vizsgált 5 biztosító vagyona, 2017 év végi adatok alapján (M Ft)

Forrás: Magyar biz̨tositók évkönyve, 2018 - saját szerkesztés

Érdekes megfigyelni, hogy a díjbevételek és piaci részesedés szerint csupán 5. helyen álló NN biztosító a vagyon alapján a legjobb pozíciót mondhatja magáénak. Még a Generali mutat hasonló negatív korrelációt (eredményben 4., míg díjbevételek és piaci részesedés alapján a 2.).

A Magyar biztosítók évkönyve és a Biztosítók Magyarországon weboldal adatai alapján 32 biztosítót vizsgáltunk. A minden intézményre kiterjedő adatokból az 1. táblában láthatjuk az 5 legnagyobb vagyonú biztosítót is, és azokat, amelyeket még rajtuk kívül felkerestünk a kérdőívünkkel.

1. táblázat. A biztosítók CSR/TF/FF tevékenysége a weboldalak alapján

\begin{tabular}{|c|c|c|c|}
\hline & Biztosító & $\begin{array}{l}\text { CSR jelentés } \\
\text { (jellemzője) }\end{array}$ & $\begin{array}{c}\text { webcím (ha van, a CSR tevékenység } \\
\text { webcíme) }\end{array}$ \\
\hline 1 & AEGON & $\begin{array}{l}\text { részletesen a } 2 . \\
\text { táblában }\end{array}$ & $\begin{array}{c}\text { https://www.aegon.hu/aegonrol/tarsa } \\
\text { dalmi-felelossegvallalas.html }\end{array}$ \\
\hline 4 & $\begin{array}{c}\text { ALLIANZ } \\
\text { HUNGÁRIA }\end{array}$ & $\begin{array}{l}\text { részletesen a } 2 . \\
\text { táblában }\end{array}$ & $\begin{array}{c}\text { https://www.allianz.hu/hu/tarsadalmi } \\
\text {-felelossegvallalas/tarsadalmi- } \\
\text { felelossegvallalas.html/ }\end{array}$ \\
\hline 12 & ERSTE & részletes & $\begin{array}{l}\text { https://www.erstebank.hu/hu/ebh- } \\
\text { nyito/bankunkrol/erste-bank-hungary- } \\
\text { zrt/tarsadalmi-felelossegvallalas }\end{array}$ \\
\hline 15 & GENERALI & $\begin{array}{l}\text { részletesen a } 2 . \\
\text { táblában }\end{array}$ & $\begin{array}{c}\text { https://www.generali.hu/Rolunk/Fen } \\
\text { ntarthato-jovo.aspx }\end{array}$ \\
\hline 18 & GROUPAMA & $\begin{array}{l}\text { részletesen a } 2 . \\
\text { táblában }\end{array}$ & https://www.groupama.hu/hu/Rolun \\
\hline
\end{tabular}




\begin{tabular}{|c|c|c|c|}
\hline 19 & K\&H Biztosító Zrt. & $\begin{array}{l}\text { részletes }(2006, \ldots \text {, } \\
\quad 2017 \mathrm{PDF})\end{array}$ & $\begin{array}{c}\text { https://www.kh.hu/documents/20184 } \\
\text { /490492/K\%26H+Csoport+fenntarth } \\
\text { atósági+jelentés+2017/5bef8a30-cc1f- } \\
\text { 4d3d-b551-531a3e26d3d4 }\end{array}$ \\
\hline 20 & $\begin{array}{l}\text { KÖBE Közép- } \\
\text { európai Kölcsönös } \\
\text { Biztosító Egyesület }\end{array}$ & részletes & $\begin{array}{l}\text { https://www.kobe.hu/kobewww/rolu } \\
\text { nk/tarsadalmi_felelossegvallalas }\end{array}$ \\
\hline 21 & $\begin{array}{l}\text { MAGYAR POSTA } \\
\text { Biztosító Zrt. }\end{array}$ & $\begin{array}{l}\text { egyszerű (magyar } \\
\text { olimpikonok } \\
\text { támogatása) }\end{array}$ & $\begin{array}{c}\text { https://www.postabiztosito.hu/Magu } \\
\text { nkrol/EvesJelentesek.aspx }\end{array}$ \\
\hline 25 & $\begin{array}{l}\text { METLIFE Europe } \\
\text { Limited Magyarországi } \\
\text { Fiók }\end{array}$ & $\begin{array}{l}\text { egyszerű (pü-i } \\
\text { tájékoztatás, } \\
\text { önkéntesség) }\end{array}$ & $\begin{array}{c}\text { https://www.metlife.hu/rolunk/tarsad } \\
\text { almifelelossegvallalas/ }\end{array}$ \\
\hline 26 & NN Biztosító Zrt. & $\begin{array}{l}\text { részletesen a } 2 . \\
\text { táblában } \\
\text { egyszerű }\end{array}$ & $\begin{array}{l}\text { https://www.nn.hu/az-nn- } \\
\text { rol/tarsadalmi-felelossegvallalas }\end{array}$ \\
\hline 28 & $\begin{array}{l}\text { SIGNAL IDUNA } \\
\text { Biztosító Zrt. }\end{array}$ & $\begin{array}{l}\text { (Transparency } \\
\text { International } \\
\text { Hungary támogatása, } \\
\text { szűroőprogramok, } \\
\text { önkéntesség) }\end{array}$ & $\begin{array}{l}\text { http://www.signal.hu/hu/tarsadalmi- } \\
\text { felelossegvallalasunk }\end{array}$ \\
\hline 29 & $\begin{array}{l}\text { UNION Vienna } \\
\text { Insurance Group } \\
\text { Biztosító Zrt. }\end{array}$ & $\begin{array}{c}\text { egyszerű (Esélyt } \\
\text { adunk program, } \\
\text { Zöld lépesek } \\
\text { program, } \\
\text { önkéntesség) }\end{array}$ & $\begin{array}{l}\text { https://union.hu/tarsadalmi- } \\
\text { felelossegvallalas }\end{array}$ \\
\hline 30 & UNIQA Biztosító Zrt. & $\begin{array}{c}\text { egyszerű } \\
\text { (jótékonykodás) }\end{array}$ & https://www.uniqa.hu/nyitolap \\
\hline
\end{tabular}

Forrás: Biztosítok weboldala, saját szerkesztés

Közülük 16 biztosító végez CSR/TF/FF tevékenységet - legalábbis a weboldaluk tartalma szerint -, azaz az intézmények fele kedvező elbírálás alá esik vizsgálatunk szempontjából. Igaz közülük hat csak az egyszerűbb társdalami felelősségvállalás irányába mozdult, úgy, mint jótékonyság, támogatás, adomány, illetve pénzügyi tájékoztatás és szűrôprogramok (bár ez utóbbi tartalmasabb, mint a versenysport szponzoráció).

Az 1. hipotézisünk megdőlt, nemcsak a nagy biztosítók tartják fontosnak, és végeznek kereteiken belül - CSR/TF/FF tevékenységet. Ugyanakkor árnyalja a képet, hogy az 5 legnagyobb biztosítón kívül a CSR tevékenységet végző intézetek többsége jelentős mértékű, hagyományos pénzügyi - banki szolgáltatásokat is nyújt (pl. Erste, K\&H). Ez nyilván jelentősebb anyagi kereteket biztosít a társaság számára a társadalmi felelősségvállalás terén is.

A legnagyobb 5 biztosító CSR tevékenységét elemezzük a továbbiakban. (2. tábla). A biztosítók weboldalán fellelhető CSR/TF/FF jelentések, tájékoztatók alapján megállapítható, hogy a naprakészségük eltérő, 2015-2018 között íródtak. A legfrissebb az NN-é (2018), a legrégebbi az Allianz-é (2015).

A legrészletesebb jelentés a piacvezető (díjbevétel és piaci részesedés alapján) Allianz biztosítótársaságé, aki - nyilván anyagi lehetőségei függvényében - legkorábban lépett a 
CSR terén, felismerve a benne rejlő pozitív lehetőségeket. A többi biztosító mintegy az Allianz nyomdokaiban haladva, kis késéssel dolgozta ki, illetve valósította meg a saját CSR eszközrendszerét.

A biztosítók láthatóan nem egyformán értelmezik a társadalmi felelősségvállalás fogalmát: mutatja ezt egyrészt a jelentések eltérő elnevezése (CSR/TF/FF jelentés), másrészt az ilyen irányú tevékenységben megjelenő érintettek különböző súlyozása. Az alkalmazottak felé irányuló CSR nagy részletességgel csak az Allianznál jelenik meg, az ügyfelekre is csak 2 biztosító fordít figyelmet a jelentésben az ötből (Generali, Groupama), ám ők is csak általános megfogalmazásokat használnak. Így ezeket az összehasonlításokat nem tárgyaljuk.

Az 5 piacvezető biztosító CSR tevékenysége nagyjából hasonló területekre fókuszál: támogatásokra (oktatás - kultúra - sport), alkalmazottai önkéntességére, és a környezetért érzett felelősség irányába alkalmazott eszközökre (zöld-programok: papírmentesítés, energiatakarékosság, szelektív hulladékgyűjtés).

A legnagyobb egyezés a támogatás/szponzoráció területén belül is a sport támogatásában mutatkozik meg. Megfigyelhetők a biztosítók által kiemelt sportágak, továbbá országos vagy nemzetközi jellegú támogatások. Az Aegon a magyar kézilabdával (MKSZ), az NN a focival (MLSZ, ill. az FTC), a vízilabdával (FTC) és a kézilabdával (Pick Szeged), az Allianz pedig a Forma 1-vel kötelezte el magát.

Erősen megkérdőjelezhető az országos hírnevű csapatok támogatását társadalmi felelősségvállalás címszó alatt szerepeltetni. Sokkal inkább reklámnak, marketing fogásnak mondhatnánk a szponzoráció következtében...

Ugyanakkor léteznek a nagyközönség számára meghirdetett programok is a sport és egészségmegőrzés terén: az NN a futókat (minden résztvevőt) támogatja futóversenyek szervezésével. A Generali csak egészségügyi szűrővizsgálatokat szervez, de ez utóbbiak nyitottak mindenki ellőtt, így inkább illeszkednek a CSR valós fogalomkörébe.

Az oktatás támogatása fontos szegmens, hiszen a lakosság pénzügyi tudatosság felé való nyitottsága, hozzáértő aktív tevékenysége minden pénzintézet számára - és persze a társadalom számára is - kívánatos cél lehet. Megállapíthatjuk, hogy mind az 5 vizsgált nagy biztosító rendelkezik ilyen jellegű akcióprogrammal. Kiemelten kezelik ebben a fiatalok érzékenyítését e téma iránt, akiket vetélkedők formájában érnek el, vonnak be az ismeretszerzésbe (Aegon, Allianz, NN).

Az egészségmegórzés illetve a biætonság ugyanakkor még inkább a biztosító intézetek profiljába vág, figyelembe véve az alaptevékenységeiket: élet-, nyugdij-, egészség-, gépjármű-, lakás-biztosítások, illetve kármegelőzés. Ezek mind az 5 nagy biztosítónál hangsúlyos szerepet kapnak, ilyen-olyan formában: az Aegon a kármegelőzésre, az Allianz a balesetmegelőzésre és rehabilitációra, a Generali a szűrővizsgálatokra, a Groupama az autóbaleset megelőzésre, az NN pedig a tömegsportra összpontosít.

A 2. feltevésünk igazolódott; nincs lényeges eltérés a nagy biztosítók CSR tevékenysége között. 
Nézzük a különbségeket! A biztosítók felelős működésével, speciális szolgáltatásaival és a szakmai tudás átadásával szorosan összefügg olyan programok támogatása, ami bevonja a fiatalokat a biztositó társaság tényleges munkájába. Egyedül az NN valósított meg ilyen CSR aktivitást: „Árnyék-program” néven felsőoktatásban tanuló hallgatókat, és „Integromprogram" néven roma fiatalokat von be a cég napi szintű feladatainak megfigyelésébe, kipróbálásába.

A biztosítói támogatások eltérést mutatnak a müvészet és a tudomány szponzorálása terén. A művészet felkarolására csak 3 biztosítónál van keret vagy affinitás az ötből: az Aegonnál irodalom témában kortárs művészeti díj formájában, a Groupamánál a Vígszínház, és az Allainznál természetfilmek, zenei fesztivál szponzorálásában.

A tudomány nagyobb volumenű támogatása pedig csak 2 intézménynél jelenik meg, az Allianz és az NN biztosítóknál (a legjobb gazdasági eredményességi mutatókkal rendelkezőknél), mégpedig országos ill. nemzetközi tudományos konferenciák formájában.

Az alkealmazottak önkéntes segitő tevékenységét sem építi be a CSR-be mind az öt nagy biztosító: csak az Aegon, az Allianz és a Genarali épít dolgozóinak aktív karitatív tevékenységére és adományaira. Főként a rászorulók, hátrányos helyzetűek segítésében nyilvánul ez meg (kiemelten a gyermekeknek nyújtott támogatásban), illetve véradás formájában.

A környezeti felelósségvállalás terén az Allianz biztosító érdemel csak figyelmet. A hagyományosnak mondható technikákon túl (papírmentesítés, szelektív hulladékkezelés, energiatakarékosság), itt figyelhetünk meg egyedül innovatív megoldásokat, úgy, mint pl. az esővíz újrahasznosítása.

2. táblázat. Biztosítók CSR / Társadalmi felelősségvállalás / Fenntartható fejlődés tevékenysége

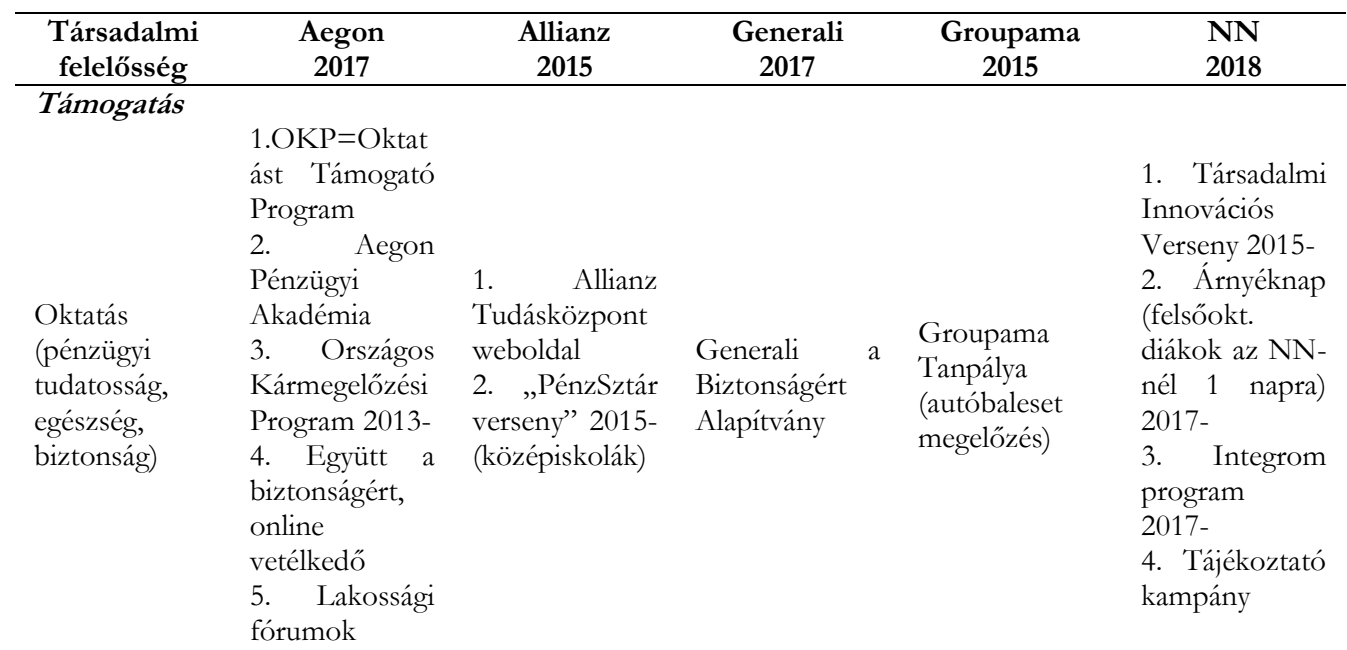




\begin{tabular}{|c|c|c|c|c|c|}
\hline $\begin{array}{l}\text { Társadalmi } \\
\text { felelősség }\end{array}$ & $\begin{array}{c}\text { Aegon } \\
2017 \\
\end{array}$ & $\begin{array}{l}\text { Allianz } \\
2015 \\
\end{array}$ & $\begin{array}{c}\text { Generali } \\
2017 \\
\end{array}$ & $\begin{array}{c}\text { Groupama } \\
2015 \\
\end{array}$ & $\begin{array}{l}\text { NN } \\
2018 \\
\end{array}$ \\
\hline 更 & $\begin{array}{l}\text { Aegon Kortárs } \\
\text { Mûvészeti Dij } \\
\text { 2006- }\end{array}$ & $\begin{array}{l}\text { 1. Nemzetközi } \\
\text { Természetfilm } \\
\text { Fesztivál 2015- } \\
\text { 2.Arcus } \\
\text { Temporum: } \\
\text { Pannonhalmi } \\
\text { Főapátság } \\
\text { zenei } \\
\text { művészeti } \\
\text { fesztivál } \\
\text { 1. „Közös } \\
\text { jövőnk” } \\
\text { konferencia, } \\
2014 \\
2 . \quad \text { Pénzügyi } \\
\text { tudatosság } \\
\text { konf. } \\
\text { 3. Baleset } \\
\text { megelőzési } \\
\text { kutatóközpont }\end{array}$ & & Vígszínház & $\begin{array}{l}\text { TEDxYouth@ } \\
\text { Bp } \\
\text { konferencia, } \\
2015,2017\end{array}$ \\
\hline $\begin{array}{l}\text { Sport, } \\
\text { Egészség }\end{array}$ & $\begin{array}{l}\text { Kézilabda } \\
\text { 2016- (Magyar } \\
\text { Kézilabda } \\
\text { Szövetség) }\end{array}$ & $\begin{array}{l}\text { 1. Allianz } \\
\text { Junior Foci } \\
\text { tábor 2016- } \\
\text { 2. F1 2000- } \\
\text { 3. } \\
\text { Rehabilitációs } \\
\text { füzet } \\
\text { 4. Családi } \\
\text { hétvége- } \\
\text { Mogyoród, } \\
\text { 2014 } \\
\text { 5. Nemzetközi } \\
\text { Paralimpia } \\
\text { Bizottság } \\
\text { támogatója } \\
\text { 2006- } \\
\text { (6. Allianz } \\
\text { Aréna - } \\
\text { Bayern } \\
\text { München) }\end{array}$ & $\begin{array}{l}\text { 1.Szűrővizsgála } \\
\text { tok az } \\
\text { országban }\end{array}$ & $\begin{array}{l}\text { 1.Football, } \\
\text { FTC, 2014- } \\
\text { 2.Vizilabda, } \\
\text { FTC 2018- } \\
\text { 3.Groupama } \\
\text { Aréna } \\
\text { 4.FTC } \\
\text { szurkolói } \\
\text { balesetbiztosítá } \\
\text { si kártya } \\
\text { 5.MLSZ, 2010- } \\
\text { 6.Kézilabda, } \\
\text { Mol-Pick } \\
\text { Szeged, 2018- }\end{array}$ & $\begin{array}{l}\text { 1. NN } \\
\text { Ultrabalaton } \\
\text { 2015- } \\
\text { 2. NN Family } \\
\text { Run 2015- } \\
\text { 3. NN Night } \\
\text { Run Bp } 2017 \\
\text { 3. Wizz Air } \\
\text { félmaraton } \\
\text { 2018- }\end{array}$ \\
\hline $\begin{array}{l}\text { Alkalmazot- } \\
\text { tak önkén- } \\
\text { tessége, } \\
\text { adományai, } \\
\text { karitatív } \\
\text { tevékenysé- } \\
\text { ge }\end{array}$ & $\begin{array}{l}\text { 1. Globális } \\
\text { önkéntes nap } \\
\text { 2. Karácsonyi } \\
\text { cipösdoboz } \\
\text { ajándék 2010- }\end{array}$ & $\begin{array}{l}\text { 1. Véradás } \\
\text { 2. Érzékenyítés } \\
\text { 3. Önkéntes } \\
\text { nap: } \\
\text { intézmények } \\
\text { szebbé tétele }\end{array}$ & $\begin{array}{l}\text { Generali a } \\
\text { Biztonságért } \\
\text { Alapítvány: } \\
\text { 1.Mosolyvadás } \\
\text { z program } \\
\text { (gyermekottho } \\
\text { nok) } \\
\text { 2. Hátrányos } \\
\text { helyzetủek } \\
\text { támogatása }\end{array}$ & & \\
\hline Egyéb & & $\begin{array}{l}\text { Korrupció } \\
\text { ellenes } \\
\text { intézkedések }\end{array}$ & & & \\
\hline
\end{tabular}




\begin{tabular}{|c|c|c|c|c|c|}
\hline $\begin{array}{l}\text { Társadalmi } \\
\text { felelősség }\end{array}$ & $\begin{array}{l}\text { Aegon } \\
2017 \\
\end{array}$ & $\begin{array}{l}\text { Allianz } \\
2015 \\
\end{array}$ & $\begin{array}{l}\text { Generali } \\
2017\end{array}$ & $\begin{array}{l}\text { Groupama } \\
2015\end{array}$ & $\begin{array}{l}\text { NN } \\
2018 \\
\end{array}$ \\
\hline $\begin{array}{l}\text { Környezeti } \\
\text { felelösség } \\
\text { Papír- } \\
\text { mentesítés }\end{array}$ & & $\mathrm{x}$ & $\mathrm{x}$ & & $\mathrm{x}$ \\
\hline Zöld iroda & & $\begin{array}{l}\text { x } \\
\text { „zöld székház” } \\
\text { (szigetelés, } \\
\text { napkollektor, } \\
\text { tisztított víz) }\end{array}$ & & & \\
\hline $\begin{array}{l}\text { Szelektív } \\
\text { hulladék }\end{array}$ & & 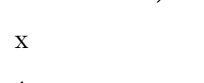 & $\mathrm{x}$ & & \\
\hline $\begin{array}{l}\text { Energiataka- } \\
\text { rékosság, } \\
\text { Fény-források }\end{array}$ & & $\begin{array}{l}\text { 1. } \\
\text { Energiatakarék } \\
\text { os égők, } \\
\text { mozgásérzékel } \\
\text { ő fényf. } \\
\text { 2. WWWW Föld } \\
\text { órája 2015- } \\
\text { 1. Esốví } \\
\text { üjrahasználat } \\
\text { 2. Tisztitott vír } \\
\text { az irodákban }\end{array}$ & $\begin{array}{l}\text { 1.Csúszásgátló } \\
\text { útburkolatoke } \\
\text { finanszírozása }\end{array}$ & $\mathrm{x}$ & \\
\hline
\end{tabular}

Áttekintve a biztosítók CSR/TF/FF programjait, illetve annak feltételezett költségigényét, kijelenthető, hogy a legszélesebb körű CSR tevékenység a támogatások terén tapasztalható, és ebből adódóan a legnagyobb összegeket támogatásokra/szponzorációra fordítják.

A 3. hipotézisünk is igazolódott, a támogatások adják a CSR tevékenység döntő részét.

\section{A kérdőíves kutatás eredményei}

Kérdőívünk 14 kérdést tartalmazott, 13 biztosítónak küldtük ki e-mailben a 32-ből (köztük az öt nagy, részletesen vizsgált intézetnek), a www.ripet.hu kérdőívszerkesztőt használtuk. Sajnos csupán 3 értékelhető válasz érkezett vissza (1 nagy és 2 kisebb biztosítótól). Ebből általánosítani természetesen nem szabd, mégis lehetôség nyílik nem publikus adatok megszerzésére.

1. Három biztosító töltötte ki kérdőívünket a megkeresett 13-ból (3/13=> 23\%-os válaszadási arány), ezen belül egy nagy - az előző fejezetben vizsgált - biztosító volt az 5-ből (1/5=>20\%-os v.a.).

2. CSR tevékenységüket a válaszadók 2007-2017 évek között szóródóan kęadték. Jellemzően a külföldi tulajdonossal rendelkezők, korábban. Ez jelzi, hogy tőlünk nyugatra előbbre tart a CSR.

3. Sikeres CSR tevékenységként, büsðkeségükként az adományokat, a pénzügyi-, természetbeni-, kommunikációs-, és humán támogatásokat, illetve a támogatott intézeteket/partnereket említik a válaszadók. Két kis biztosító konkrét válasza az alábbi: 
„Vállalatunk a teljes CSR programjára büszke. PARTNEREINK: Bátor Tábor, Fejér Megyei Gyermekevédelmi Alapituány, Kézenfogva Alapitvány, Nem Adom Fel Alapitvány, Magyar Vöröskeresžt, Magyar Élelmiszzerbank, Piros Orr Bohócdoktorok, Amadeus Müvészęti Alapitvány. Támogatási formáink sokszinüek, a pénzïgyi segitségen felül természetbeni, kommunikációs és bumán (önkéntes munka) támogatásokat egyaránt nyújtunk partnereinknek és tevékenység̈̈nkben kiemelt szereep jut az edukációnak, a közös programoknak. Fontosnak tarjuk, bogy támogatottjaink és kollégaink között kötódés alakuljon ki." (Union Biztosító)

„A Magyar Máltai Szeretetszolgálat (MMSZ) Kerekitsd fel! elnevezésü programjához.

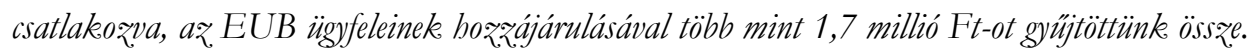
Az adományból az. MMSZ a Mentöszolgálat javára 2 db video laringoszkópot vásárolt, amely az. életveszélyes állapotban lévó betegek lélegeztetésének elökészitéséhez, használható. A jelenleg futó kampányunk során betegszállitó autóra gyüjtünk. A Budapesten megmütött fejüknél összenött bangladesi sziámi ikerpár és családjának biztositása (természetesen itt az utą̧ással kapcsolatos utasbiztositásról van sæó, nem pedig a mütéttel kapcsolatos kockáza tok fedezetéröl). A Generali Csoport tagjaként mi is klimatudatos és energiatakarékos módon folytatjuk müködésinkeet: papirbasználatunk csökkent, hosszabb távon a teljesen papirmentes müködés a célunk, korszerü vilagitással, szelektiv bulladék.gyüjtéssel, böszigetelo" nyilászárókekal üzemeltetett épületben dolgozunk." (Európai Utazási Biztosító)

4. CSR/TF/FF jelentéseiket a biztosítók jellemzően a weboldalukon kommunikálják, de vannak, akik más internetes és médiafelületeket is használnak a tájékoztatásra.

5. Több biztosító tartja fontosabbnak a CSR programok cégen belüli kommunikációját, kevesebben vélik úgy, hogy a külsố és belsö kommunikáció egyformán fontos.

6. Arra a kérdésre, hogy milyen gyakran készítenek CSR/TF/FF jelentést, csak egy biztosító válaszolt (nagy biztosító), aki két évente vizsgálja felül, aktualizálja, illetve bővíti ilyen irányú tevékenységének nyilvános dokumentumát. Vélhetően a szerényebb anyagi lehetőségú cégeknek nincs erre kapacitásuk.

7. Van külön költségvetése a CSR tevékenységnek a válaszadók kétharmadánál, azaz tervezetten költenek a társadalmi felelősségvállalás megvalósítására.

8. A szervezeten belül a marketing-, PR-, kommunikációs osztály felelős minden válaszadó cégnél a CSR tevékenység koordinálásáért. Ez az eredmény is azt erősíti meg, hogy a biztosítók nagy része inkább reklám lehetőséget lát a CSR tevékenységben, mint önzetlen (esetleg névtelen) segítést.

9. Talán a legizgalmasabb kérdés az volt, hogy mekkora összeget költenek a biztosítók az éves eredményük százalékában CSR tevékenységre. Erre sajnos csak egy biztosító válaszolt: éves eredményük kevesebb, mint 3\%-át. Ez az arány elszomorítóan alacsony.

10. A szponzoráció/támogatás az éves CSR tevékenységre fordított összeg kevesebb, mint 25\%-át teszi ki minden válaszoló biztosítónál. Mivel a kérdésre 1 kis és 1 nagy biztosító válaszolt, nem általánosítható a megállapítás. Különösen a nagy biztosító(k) esetén kérdőjelezhetô meg ez az arány, hiszen a 2.sz. táblázatban részletezett CSR tevékenységek közül a támogatás rendelkezik a legszélesebb spektrummal. (A 
mostani vizsgálati keretek nem voltak elegendők ennek a kérdésnek a tisztázására, ám a további kutatások irányát jelezheti; a személyes interjúk és a céges kimutatásokba való betekintés pontosabb képet adhatnak).

11. A CSR tevékenységnek csak pozitiv hatása van a válaszadók szerint: munkatárs megtartó erőt ad, élénkíti a csapatszellemet, érzékenyíti az alkalmazottakat, ugyanakkor a támogatottak öröme visszahat a cégre, illetve az ügyfelek méltányolják ezeket a törekvéseket. (Ezeket a válaszokat két kis biztosító adta, a nagy nem felelt erre a kérdésre.) Két kis biztosító konkrét válasza:

„Negativ hatás természetesen nincs. Pozitív hatás: - employer branding elemmé vált, munkatárs megtartó erôvel bír - csapatszellemet szolgálja - érzékennyités - támogatott partnreink öröme visszahat.” (Union Biztosító)

„Közvetlen pozitiv vagy negatív hatását nem feltétlen érzékeljüik, de a Kerekitsd fel! kampány során kiderült, hogy ügyfeleink méltányolják a törekvéseinket, hiszen sokan voltak hajlandók felkerekiteni a vásárlás összegét a nemes cél érdekében.” (Európai Utazási Biztosító)

12. A biztosítók vezetése, tulajdonosai az 1-5-ös skálán átlagosan 4-es fontosságúnak érzik a CSR tevékenységet (két válasz volt: egyik 5-ös, azaz teljes mértékben fontos, a másik 3-as, azaz csak közepesen).

13. A CSR tevékenységnek PR jelentösége átlagosan 3-as az 1-5-ös skálán; a válaszadók kétharmada 2-es adott meg, egyharmaduk 5-öst. Azaz többségük - helyesen - nem a cég imázsának javításában látják a CSR lényegét.

14. A két válaszoló kisebb biztosító hozzájárult a kérdőív kiértékeléskor történő nevesítéséhez (Európai Utazási-, és Union Biztosító), az egy nagy, nem.

Egy hipotézisünk épült a kérdőívre (H4): A CSR tevékenységre az éves múködési eredményadatok kisebb, mint 5\%-át költik a biztosítók. Igaz, csak egy válasz alapján, de megerősítést nyert a feltevésünk.

\section{KÖVETKEZTETÉSEK, ÖSSZEGZÉS}

Kutatásunk a CSR elterjedtségét vizsgálta a piaci szereplők egy szegmensében, a biztosító társaságoknál. A cégek weboldalán található CSR jelentések alapján dolgoztuk fel a témát, továbbá kérdő́ivet juttattunk el a 32-ből 13 biztosító részére, akik végeznek ilyen irányú tevékenységet (sajnos csak 3 biztosító válaszolt... A további kutatás szükségessé teszi a személyes interjúkat). Az 5 legnagyobb vagyonú biztosító CSR tevékenységét vizsgáltuk meg részletesen.

A biztosító társaságok fele foglalkozik a társadalmi felelősségvállalás ilyen-olyan szintű megvalósításával, akik között nem csak jelentős anyagi háttérrel rendelkezők vannak. (Lehetséges, hogy még többen is foglalkoznak CSR-ral, csak még nem publikálják nyilvánosan, háttérben maradnak - tudatosan vagy lustaságból.) Örömteli, hogy a gazdálkodó cégek és a banki szféra nyomdokain haladva a biztosítási piacon is egyre nagyobb teret hódít a CSR. A kisebb biztosítók fơként támogatások, adományok formájában, míg a nagyok szélesebb körű akciókkal valósítják meg a CSR teendőket. Ám kiemeljük, hogy még a nagyobb biztosítók is a támogatásokra, szponzorációra helyezik a 
hangsúlyt, ennek a spektruma a legnagyobb. Bár a személyes megkeresésből érzékelhető, hogy a válaszoló szakemberek tisztában vannak a CSR önzetlenül segítő alapkövetelményével, ám mégis általános, hogy a marketinghez, az imázs építéséhez kötik mind szervezetileg, mind hatását tekintve.

A nagy biztosító társaságok CSR tevékenysége nem tér el lényegesen egymástól: támogatásokra, az alkalmazottak önkéntességére és a környezet kímélésére építenek. Fontos kihangsúlyozni, hogy az oktatás terén igyekeznek a lakosságot és főleg a fiatalokat érzékenyíteni az egészségmegőrzés, a baleset- és kármegelőzés, továbbá a biztonság és a biztosítások, mint pénzügyi szolgáltatások terén. Közös sajátosság a sport, egészség kiemelt megjelenése a támogatásokban, ám több biztosító is országos hírű sportklubokat vagy magyar válogatottat szponzorál, ami nem feltétlenül jelent valódi társadalmi felelősségvállalást, sokkal inkább reklámfelületet a biztosító intézet számára. A tudomány és a kultúra támogatását, illetve az alkalmazottak önkéntességét nem azonos mértékben alkalmazzák még a nagy biztosítók sem.

Bár kevés válasz érkezett a kérdőívre, de megerősödött az az előzetes feltevésünk, hogy a CSR tevékenységre - még ha tervezetten benne is van a költségvetésben - az éves eredmény nagyon alacsony arányát, kevesebb, mint 5\%-át költik. A CSR tevékenység pozitív hozománya közé sorolták a válaszoló cégek a támogatottak és az ügyfelek méltányoló elismerését, de a munkatársak megtartó erejét és a csapatszellem erôsítését is. A kutatás eredménye viszonylag világos következtetések levonását teszi lehetővé annak ellenére, hogy látszólagos sokszínűséggel találkoztunk. A legfontosabb megállapítások a következőkben foglalhatók össze:

\section{Pozitívumok}

A CSR ma a köztudat részévé vált a jelentősebb gazdasági szereplők esetében. Olyan elem, amelyet „kultúrember” nem hagyhat figyelmen kívül. Ebből a szempontból a biztosítók az átlag feletti elkötelezettséget képviselik. Érzékelik a társadalmi elvárást abban a tekintetben, hogy a tulajdonosnak és a menedzsmentnek jó példával kell elől járnia.

A biztosítók körében is egyre nagyobb az elterjedése a társadalmi felelősségvállalásnak. Méret, illetve vagyonfüggő az ilyen irányú tevékenység volumene. A nagy biztosítók részletesen kidolgozott, megvalósított CSR tevékenységet folytatnak.

A CSR/TF/FF tevékenység kommunikációja megfelelő, a biztosítók weboldalán megtalálhatók ebben a témában a jelentések. A nagy biztosítók 2 évente frissíti ezeket.

A biztosítók CSR/TF/FF tevékenysége nem tér el jelentôsen. Legnagyobb aránya a támogatásoknak, szponzorációnak van, ami kiterjed az oktatásra, kultúrára és a sportra, egészségmegőrzésre. Továbbá minden biztosító a természeti környezet megóvása irányába is tesz lépéseket ilyen-olyan eszközökkel.

Büszkék a társadalmi felelősségvállalásukra. 


\section{Negatívumok}

A biztosítók CSR/TF/FF tevékenységében elsődleges a PR, reklám, imázsépítés, és csak másodlagos a tudatos stratégia (kötelező házi feladatként jelenik meg), nincs beépülve a vállalati napi múködésbe.

Általában a PR szervezethez delegálják - esetleg a HR-hez - és kampányszerüen foglalkoznak vele. A kiküldött kérdőívek kitöltésének „elfelejtődése” mutatja, hogy nincs a CSR-hez naprakész státusz hozzárendelve, és a témáért felelős vezető nem mer céges véleményt közölni felsővezetői útmutatás és jóváhagyás nélkül.

A CSR keret felhasználás domináns részét képezi a szponzoráció, ami sok esetben a biztosító reklámfelületeken való megjelenítését szolgálja, nem a társadalom érdekét.

A biztosítók az eredményük nagyon kis hányadát fordítják CSR/TF/FF tevékenységre, ami növelhető lenne.

A források felhasználása között általában az elsőszámú vezető személyes kötődése, vonzalma meghatározó módon fedezhető fel. A döntés iránya nem tudatos felelőségvállalási koncepció, céges szándék, hanem szubjektív elemek által meghatározott.

Ugyan vállalati konferenciák, belső marketing anyagok keretében megjelenik a cég ilyen irányú költése a belső kommunikációban, azonban korántsem állítható, hogy ezt hangsúlyosan, identitás képző erőként használná a menedzsment.

Egyértelműen érzékelhető, hogy a biztosító cégek büszkék Társadalmi Felelősség Vállalási tevékenységükre. Az szinte biztosra vehető, hogy a környezeti kihívások és a közösségek alapvetően humánus jellege miatt e fontos területen egyre cizelláltabb és elkötelezettebb munka fog folyni. Joggal reménykedhetünk abban is, hogy a társadalmiés egyéni kockázatkezelés gyakorlatát és következményit jól ismerő pénzügyi szektor élenjáró szereplő lesz a hosszútávú társadalmi nehézségek enyhítésének szép kihívásában.

\section{FELHASZNÁLT IRODALOM}

BARCLIFT, Z. J. (2012): Corporate Social Responsibility and Financial Institutions: Beyond DoddFrank. Banking \& Financial Services Policy Report. Volume 31, number 1, Januar

BRAUN Róbert (2007): Felelősségvállalás a pénzügyi szektorban: Transzparencia és hitelesség. https://www.mnb.hu/letoltes/20070522-23-braun-robert-1.pdf

Carroll, A. B. (1979): A Three-Dimensional Model of Corporate Performance. Academy of Management Review, 4(4): pp. 497-505. https://doi.org/10.2307/257850.

CArroll, A. B. (1991): The Pyramid of Corporate Social Responsibility: Toward the Moral Management of Organizational Stakeholders. Business Horizons, July-August.

DALHSRUD, A. (2008): How corporate social responsibility is defined: an analysis of 37 definitions. Corporate Social Responsibility and Environmental Management. 15(1) pp. 1-13. https://doi.org/10.1002/csr.132.

DoDD, E. M. Jr. (1932): For Whom are Corporate Managers Trustees? Harvard Law Review 45(7) pp. 1145-1163. https://doi.org/10.2307/1331697. 
EVAN, W. M. - FREEMAN, R. E. (1996): A modern vállalat stakeholder-elmélete: kantiánus kapitalizmus. In: Boda Zs. - Radácsi L. (1996). Vállalati etika. BKE Vezetőképző Intézet, Budapest pp. 93-108.

LENTNER Csaba - SzEgEDI Krisztina - TATAY Tibor (2017): Társadalmi felelősség a központi bankok múködésében. Hitelintézeti Szemle, 16. évf. 2. szám, 2017. június, pp. 64-85.

LENTNER Csaba - Szegedi Krisztina - TATAY Tibor (2015): Társadalmi felelősségvállalás a bankszektorban. Pénzügyi szemle, 2015.1. pp. 96-104.

RAngan, V. K. - Chase, L. - KARIM, S. (2015): The Truth About CSR. Harvard Business Review, January-February pp. 40-49.

SZEGEDI Krisztina (2014): Possibilities of Corporate Social Responsibility. In: BERÉNYI L. (Ed.) (2014): Management Challenges in the 21st Century. LAP LAMBERT Academic Publishing.

Tzu-Kuan Chiu (2014): Putting Responsible Finance to Work for Citi microfinance. Journal of Business Ethics 119 (2):1-16 (2014)

VIGANO, F. - NiCOLAI, D. (2009): CSR in the european banking sector: evidence from a survey. In: Barth, R. - Wolff, F. (ed.) (2009): Corporate Social Responsobility in Europe: Rhetoric and Realities. Edward Elgar Publishing Inc. ISBN 9781847207647

Magyar biztosítók évkönyve, 2018. https://mabisz.hu/wp-content/uploads/2018/08/evkonyv2018-magyar.pdf

Biztosítók weboldalai: (3. mellékletben mind a 32 vizsgált cég linkje szerepel)

https://www.aegon.hu/aegonrol/tarsadalmi-felelossegvallalas.html Utolsó letöltés ideje: 2019.04.01.

https://www.nn.hu/az-nn-rol/tarsadalmi-felelossegvallalas Utolsó letöltés ideje: 2019.04.01.

https://www.allianz.hu/v_1446807344000/hu/letoltheto-dokumentumok/allianz-csr-2014.pdf Utolsó letöltés ideje: 2019.04.01.

https://groupama.hu/hu/Fogyasztovedelem/fogyasztovedelmi_politikank_es_iranyelvek.html?r edirected $=$ true\# $\#$ onglets-span Utolsó letöltés ideje: 2019.04.01.

https://www.generali.hu/ /media/Ugyfelportal/Dokumentumok/Rolunk/Charter $\% 20$ of $\% 20$ Sustainability\%20Commitments_HU.ashx Utolsó letöltés ideje: 2019.04.01.

https://biztositomagazin.hu/biztositok-magyarorszagon/ Utolsó letöltés ideje: 2019.02.25. 
ISSN 2630-886X

18 国 57
BGE 